\title{
Non-positive airway pressure therapy for obstructive sleep apnea
}

\author{
Behrouz Jafari • Francoise Roux
}

Published online: 18 April 2012

(C) Springer Science+Business Media, LLC 2012

\begin{abstract}
Obstructive sleep apnea (OSA) is a common disorder associated with cardiovascular morbidity. Various methods are offered to improve symptoms of OSA and its outcome. Although positive airway pressure is the most effective treatment for OSA, its clinical effectiveness is limited by patients' compliance. Other suggested treatments for OSA focus on expanding upper airway and reducing its collapsibility. For example, mandibular advancement device (MAD) achieves this goal by mechanically protruding the mandible. Other available treatments including weight reduction, positional therapy, drugs, nasal dilators, and nasal expiratory pressure device are clearly inferior to CPAP.
\end{abstract}

Keywords Obstructive sleep apnea $\cdot$ Non-CPAP therapy · Dental device $\cdot$ Positional therapy $\cdot$ UPPP $\cdot$ Mandibular advancement device $\cdot$ Oral appliance $\cdot$ Sleep medicine

\section{Introduction}

Obstructive sleep apnea is a highly prevalent disorder characterized by recurrent upper airway obstruction during sleep resulting in a cycle of hypoxemia, increased respiratory efforts, and frequent arousals [1]. Several large epidemiological studies estimate that in Western countries, $24 \%$ of

\section{B. Jafari $\cdot$ F. Roux}

Section of Pulmonary and Critical Care Medicine,

Yale University School of Medicine,

333 Cedar Street, Post Office Box 208057, New Haven, CT

06520-8057, USA

B. Jafari $\cdot$ F. Roux $(\bowtie)$

Yale Center for Sleep Medicine,

333 Cedar Street, LCI 105, Post Office Box 208057, New Haven, CT 06520-8057, USA

e-mail: francoise.roux@yale.edu men and $15 \%$ of women have OSA and $2 \%$ of women and $4 \%$ of men have OSA with symptoms of sleepiness [2, 3]. There are many cardiovascular consequences of OSA. OSA has been proposed as an independent risk factor for the development of hypertension because it can precede and predict the onset of hypertension [4]. Most studies have found an independent association between OSA and adverse cardiovascular events, such as coronary artery disease [5] and stroke [6], emphasizing the need for optimal therapy. Many factors can contribute to the pathogenesis of OSA, including decreased pharyngeal lumen size [7, 8], reduced pharyngeal dilator muscles activity during sleep [9], and posture $[10,11]$. The supine position leads to a decrease in lung volume by approximately 0.2 liters [12]. Obesity can also cause narrowing of the pharynx by the effect of subcutaneous and peri-luminal fat deposits. Obesity can also alter compliance of the airway wall secondary to increased fat deposition thus promoting airway collapse [13]. As a result, the treatment of obstructive sleep apnea is aimed at reducing the upper airway propensity to collapse during sleep. Treatment options for OSA include postural changes, weight loss, oral devices, noninvasive mechanical ventilation, with either continuous positive airway pressure (CPAP) or bi-level positive airway pressure (BiPAP) and surgery. Since the first description of CPAP and its application in the early 1980s, it has become the standard treatment in obstructive sleep apnea syndrome [14]. However, CPAP therapy is not always very well accepted by the patients due, in part, to its pressure-related side effects and the long-term compliance with CPAP therapy can vary widely between individuals. In addition, CPAP may not, in some cases, completely alleviate the symptoms associated with OSA, such as daytime hypersomnia. Moreover, CPAP does not allow for a permanent resolution of obstructive events, but only controls them while using the device during sleep. Therefore, many 
patients prefer more comfortable or curative and less intrusive treatment options. As a result, there has been an attempt to explore other therapeutic options to treat OSA. In this article, we review the established evidence supporting an alternative option for CPAP therapy which include conservative and surgical therapeutic options.

\section{Conservative treatments}

\section{Positional therapy}

Position can significantly affect the severity of obstructive sleep apnea due to its effect on the closing pressures of the pharynx and on the ventilatory drive [15-22], especially during rapid eye movement sleep. Positional OSA is defined as a supine AHI that is doubled compared to the one in the lateral position [23-25]. It can occur independently of BMI, age, upper airway anatomy, or lung function [26, 27]. However, the patients who respond to positional therapy tend to be younger, have a milder form of OSA with a lower BMI $[15,24,25,28,29]$. Positional therapy refers to the use of postural changes during sleep to improve OSA. It usually involves avoidance of sleep in the supine position, which can be achieved through a variety of means including tennis balls or specially designed pillows. However, studies failed to show any superiority from one to another except for positional alarm which appears to be more effective than verbal instructions $[15,30]$. Positional therapy can result in moderate reductions of AHI [28, 29, 31-34], but is overall inferior to CPAP therapy [35] and its long-term compliance has been poor [33]. In contrast, a recent study [36] showed that newer positional devices could significantly reduce the apnea/hypopnea index (AHI) from a baseline of $26 / \mathrm{h}$ to $6 / \mathrm{h}$, with improvement in oxygenation and an objective compliance averaging $73.7 \%$. These beneficial effects were still present at 3 months of therapy demonstrating persistent efficacy in this selected population of patients with positional obstructive sleep apnea. In selected patients with clear positional OSA, these newer positional devices might be an attractive alternative to more conventional therapies. However, larger studies are necessary to evaluate the impact of positional therapy on cardiovascular outcomes. When positional therapy is selected to treat OSA patients, a full polysomnography (PSG) should be performed to confirm its efficacy and these patients should be followed closely.

\section{Weight reduction}

The exact mechanisms by which obesity contributes to upper airway collapse during sleep are not completely understood. Increased local fat deposition presumably compromises airway space, while abdominal obesity reduces lung volume and therefore caudal traction on the pharynx [37]. Several studies have demonstrated that pharyngeal fat deposits lead to a decrease in pharyngeal patency and underline the risk factor of obesity [38-40]. Reducing caloric intake by diet management is the most common and simplest treatment of obesity but is not very effective. Various studies have examined the effect of weight loss in patients with OSA. Weight loss can decrease the likelihood of upper airway collapse by modifying its anatomy and function. Weight reduction will lead to a decrease in critical closing pressure (Pcrit), and in the severity of OSA [41]. Hernandez et al. [42] used MRI to assess the morphology of the neck in 14 patients with BMI $>40$ after 3 months of weight loss and 3 months of weight maintenance. They found a significant reduction in the lateral subcutaneous neck fat after only a $10 \%$ weight loss. The AHI was reduced from 24.3 /hour to 2.9/hour after weight loss in these patients. The magnitude of the decrease in AHI after weight loss was higher in patients with the most severe OSA. Current data show that weight reduction not only improves breathing pattern but also increases REM and deep sleep (up to $10 \%$ and $17 \%$, respectively) as well as the AHI [43-53]. In a large population-based prospective cohort study of 690 persons, a $10 \%$ weight loss was correlated with a $26 \%$ decrease in AHI, showing that even minimal weight loss can be beneficial in patients with OSA [54]. Although weight loss reduces OSA severity, it does not necessarily resolve the disease and there is substantial individual variability in the impact of weight loss on OSA [44, 55]. Some studies showed improvement in sleep-disordered breathing after weight loss but no cure of the disorder. It is unclear which patients would benefit most from weight loss and what the critical weight loss threshold is to cure sleep-disordered breathing. Most of these studies are observational or retrospective and do not support a high level of evidence.

It is reasonable to conclude that patients with mild sleepdisordered breathing might be more likely to benefit. Unfortunately, the long-term success of weight loss in patients with sleep-disordered breathing is limited and such patients should be followed closely.

\section{Oral protrusion devices}

Oral protrusion devices are conceived to enlarge the pharyngeal airway by mechanical action. The main devices on the market are the mandibular advancement devices and the tongue retaining devices.

\section{Mandibular advancement devices (MAD)}

MADs are the most common class of oral appliance used for the treatment of snoring and OSA. During sleep there is upper airway collapse. MADs work by increasing the upper 
airway volume, predominantly by widening of the lateral dimensions of the velopharynx [56]. The treatment also aims to reduce collapsibility in order to improve the upper airway patency, reduce snoring and obstructive events during sleep $[57,58]$. It may be designed to have either a fixed amount of mandibular protrusion or adjustable protrusion to ensure adequate enlargement of the airway. Similar to CPAP, a mandibular advancement device requires nightly use for optimal effect. The reduction of the AHI by MADs has been variable but overall $52 \%$ of OSA patients experience a reduction in the AHI to less than 10/h [59]. According to several studies MADs can decrease daytime hypersomnia [60-64] to a degree comparable to CPAP therapy [62, 65-69]. However, CPAP may produce a better clinical outcome than MADs, as well as better control of snoring [65, 70-72]. MADs can have some beneficial cardiovascular effects with improvement in blood pressure control, in cardiac function, endothelial function, and oxidative markers [62, 72-79]. Several studies have demonstrated that MADs are more successful in milder sleep apnea, position dependent OSA (lateral $\mathrm{AHI}<10 / \mathrm{h}$ ), females, and in patients with a lower BMI [64, 68, 80-84]. MADs are recommended for patients with mild to moderate OSA and even for those who have severe OSA and cannot tolerate CPAP [85••]. However, these patients need to be carefully selected since the rate of contraindication for MADs can reach up to $34 \%$ [86]. Prefabricated devices are less effective [87] than the custom-made devices which need to be advanced to achieve optimal results [1, 88-90]. It is important to have a follow-up polysomnography study with the MAD in place to confirm the efficacy of this treatment modality. Side effects include tooth tenderness, jaw discomfort, excessive salivation, and temporary malocclusion [65, 66, 70-72, 80, 81, 91]. MADs are often preferred by the patients and the compliance is superior than with CPAP use [62, 69, 71].

\section{Tongue-retaining devices (TRD)}

A tongue-retaining device can be used in edentulous patients since it does not use dentition to advance tissues. Instead, TRDs use suction bulb to hold the tongue in a more advanced position and to widen the upper airway dimensions during sleep. As a result it reduces obstructive sleep apneas and snoring. A few studies show that TRDs are effective in mild to moderate OSA (but not in severe OSA) and can be as effective as MADs, however more patients prefer MADs [92-95]. Research studies have shown that using oral appliances that do not provide mandibular advancement has no significant clinical benefit for the treatment of OSA, suggesting that such a mechanism plays a significant role $[61,80]$. Therefore TRDs can be used in selected patients with mild to moderate OSA, if other treatments have failed or are not possible. Overall very few studies have been done and evidence for this device is not as strong as for MADs. Should patient or physician choose to use TRDs, a polysomnography would be useful to ensure effectiveness of therapy.

\section{Hypoglossus nerve stimulation and muscle training}

Reduced upper airway muscle activity during sleep is one of the major contributing factors in obstructive sleep apnea [96]. The importance of upper airway dilator muscles in maintaining pharyngeal stability is well established. During the transition from wakefulness to sleep the electrical activity of upper airway dilator muscles diminishes and leads to narrowing of pharyngeal area [97]. In order to counterbalance the collapsible forces, the upper airway muscles have to contract more intensively. Based on these findings, the stimulation of the upper airway muscles could, theoretically, optimize the dilating forces and enlarge the cross-sectional area of the upper airways. Electrical stimulation of the genioglossus during sleep can counteract respiratory disturbances and reduce the resistance of the upper airways both in healthy persons and OSA patients [98-103]. The stimulation of the genioglossus muscle most effectively reduces resistance and the critical pressure Pcrit [99, 101, 102]. However, there are conflicting reports on the efficacy of triggered neuro-stimulation. Some studies showed improvement of sleep parameters [98, 104]; others failed to find any effects $[105,106]$. In a recent study, the authors have shown significant improvement of AHI from 43 to 19/ $\mathrm{h}$ with hypoglossal nerve stimulation, however it failed to resolve sleep apnea [107].

Tongue muscle training by electrical stimulation is also controversial. In one case study, a decrease of the AHI, daytime sleepiness, and snoring was shown with submental transcutaneous electrical stimulation [108]. In contrast, the only placebo-controlled double-blind study on tongue muscle training found an improvement of snoring but no significant reduction of AHI [109]. In conclusion, electrical stimulation is not currently recommended as an effective treatment of OSA and some concern about the long-term safety of this mode of therapy has been raised.

\section{Drug therapy}

The compliance with CPAP therapy can vary considerably. As a result, there has been an attempt to explore other therapeutic options such as pharmacological therapy. Changes in respiratory drive and airway tone cause airway closure during sleep and are, in part, contributing factors in obstructive sleep apnea. Some medications might reduce sleep apnea by increasing respiratory drive, suppressing REM sleep, increasing upper airway muscle 
tone, and reducing forces that encourage closure of the upper airway. Several studies have shown some positive effects of protriptyline, paroxetine, and mirtazapine on sleep apnea indices [110-112]. However, the antidepressants do not dramatically impact the severity of sleepdisordered breathing despite their potential to increase upper airway tone.

Other studies, using polysomnographies, showed that cholinergic agents and upper airway lubricants could improve sleep-disordered breathing [113, 114] but residual OSA was still present. Nasal steroids might be helpful to treat obstructive sleep apnea. It is well established that allergic rhinitis is a common cause of nasal obstruction. Increased nasal resistance will induce a more negative intra-pharyngeal pressure which might promote upper airway collapse. However, the role of nasal obstruction in the pathogenesis of OSA is still debated but might be a cofactor especially among patients with mild OSA. Some reports have demonstrated subjective worsened sleep quality in patients with allergic rhinitis [115]. Conversely, other studies showed an increased prevalence of perennial allergic rhinitis in patients with OSA (11\%) compared to case controls (2.3\%) [116]. Moreover, the inflammation of the nasal mucosa may perpetuate the adeno-tonsillar hypertrophy as well as obstruction. Intranasal corticosteroids are commonly used to treat rhinitis, which significantly improve nasal obstruction symptoms and reduce adenoid size [117]. As a result, this may decrease the upper airway resistance at the nasal, adenoidal, and/or tonsillar levels. Topical nasal steroids have been found to improve subjective parameters of sleep quality such as fatigue and daytime sleepiness but had no effect on the apnea/hypopnea indices in patients with allergic rhinitis treated for 4 weeks [118]. In contrast, patients with OSA and associated rhinitis experienced some improvement in their sleep-disordered breathing after 4 weeks of intranasal corticosteroid therapy in a randomized, placebocontrolled, crossover study [119]. There was no difference in snoring between the treatment and placebo groups. Randomized controlled studies in patients with OSA and chronic nasal congestion treated with a nasal decongestant such as xylometazoline or oxymetazoline failed to demonstrate any clinically significant improvement in sleep-disordered breathing or sleep quality/daytime sleepiness [120] even when nasal resistance was reduced. Those studies would suggest that the nose is not a significant contributor to the pathogenesis of OSA but the number of patients studied is small. In conclusion, topical nasal steroids may influence sleep apnea severity both in children and adults. However, they are not recommended as a single intervention in the adult OSA population. Pharmacotherapy for OSA would be ideal since CPAP therapy is not always well accepted by patients but medications have failed to completely normalize sleep-disordered breathing. A better understanding of the physiopathology of OSA will lead to better targeted pharmacological therapies.

Nasal dilators

Increased nasal resistance may induce sleep-related breathing disorders, disturbed sleep, and may increase snoring [121]. Nasal dilators might improve sleep and breathing by widening the nostrils. There are different types of nasal dilators, but all of them dilate the anterior part of the nose, the valve region, in order to decrease resistance and increase the air flow.

In summary, the published data showed that nasal dilators are not effective in reducing snoring, or in improving sleep-disordered breathing or sleep architecture in OSA [122-124]. Therefore, they are not currently recommended for the treatment of sleep apnea.

Nasal expiratory positive airway pressure (EPAP) device

Nasal EPAP is a small, lightweight, and quiet device that does not require an external power source. It consists of a one-way valve that is inserted into the nares and secured to the outside of the nose with an adhesive substrate. The valve opens to allow for the unimpeded flow of air during inhalation but closes so that exhalation occurs against a fixed orifice. The expiratory flow resistance creates positive airway pressure during the expiratory phase, which appears to stabilize the pharynx and prevent its periodic collapse during sleep. Previous investigations including randomized double-blind studies have demonstrated that nasal EPAP device has been effective in sleep breathing disorders [125•, 126-129]. A new prospective, randomized study has shown that use of nasal EPAP resulted in $\geq 50 \%$ reduction in AHI in 3 and 12 months follow up, as well as reduction in snoring and daytime sleepiness with good compliance [125•]. However, the authors excluded patients with severe hypoxemia, those who had prior upper airway surgery, or those who had been treated with CPAP. Thus, the results of the study may not be generalized to a more heterogeneous population as well as those who have severe OSA. Overall, treatment with this novel device was well tolerated and accepted by the participants in most studies, but subjects with positional or milder SDB in the lateral position showed the best response to this modality [128]. However, the therapeutic response was variable among the participants in most of the above studies. As a result, a follow-up polysomnography should be performed to ensure efficacy with this recent treatment modality. 


\section{Surgical treatments}

\section{Nasal surgery}

Studies have shown that nasal airflow has stimulating effect on respiratory muscles as well as upper airway dilator muscle activities $[130,131]$. As a result, nasal obstruction may predispose to sleep-disordered breathing with increased number of arousals, and increase in the number of obstructive apneas and hypopneas [132-134]. In addition, nasal obstruction can hinder CPAP tolerance, providing a physiological basis for nasal surgery to improve CPAP compliance [135]. A recent study has demonstrated that nasal surgery alone was partially effective in improving sleep quality, architecture, and snoring, but it had no effect on obstructive apneas [136]. Therefore, nasal surgery may be recommended in patients with nasal obstruction to improve compliance with CPAP therapy, but has no beneficial effect as a single measure in OSA patients [85••].

\section{Tonsillectomy}

In contrast to adults, tonsillar hypertrophy is the most common cause of OSA in children. As a result, tonsillectomy and adenoidectomy is a very commonly used intervention to treat OSA in children. There is a high correlation between enlarged tonsils and OSA severity $[137,138]$. However, there is a growing awareness that residual OSA may be present despite tonsillectomy and adenoidectomy in children [139]. In adults, tonsillectomy may be beneficial by increasing the use of CPAP in patients with tonsillar hypertrophy, or when CPAP therapy is not possible as the first choice of therapy [140, 141]. Therefore, tonsillectomy as a single intervention is recommended for treatment of OSA in the presence of tonsillar hypertrophy, especially in children, but close clinical follow-up is necessary to ensure postoperative resolution of OSA.

\section{Radiofrequency surgery of the tonsils}

For over a decade, temperature-controlled radiofrequency (or known as somnoplasty) has been one of the therapeutic options for the treatment of sleep-disordered breathing, particularly for simple snoring. This procedure is based on the production of high temperatures (up to $80^{\circ} \mathrm{C}$ ) in the submucosal tissue which causes a local and controlled destruction of tissue bonds with subsequent scarring which decreases tissue thickness and increases its rigidity. This modality reduces vibration of the soft tissues of the upper airways [142].

In the last decade, several trials, using this technique, have proven its ability to decrease the intensity of snoring and improve daytime sleepiness [142-145]. However, no polysomnography was done in these studies to confirm the objective improvement of OSA [146-149]. As a result, this technique seems minimally invasive with low morbidity but there is, to date, no evidence to show efficacy in OSA. Therefore, it cannot be recommended as a single procedure to treat sleep apnea.

\section{Uvulopalatopharyngoplasty (UPPP)}

UPPP involves tonsillectomy, trimming, and reorientation of the posterior and anterior tonsillar pillars, and excision of the uvula and soft palate [150]. As a result, soft palate redundancy can be reduced and upper airway obstruction improves [150]. This technique was the dominant treatment of OSA before CPAP was generally available [151]. However, since then its role has been questioned because of side effects and limited efficacy. In a recently published metaanalysis of 15 UPPP studies, only a $33 \%$ reduction in the AHI was found after surgery [152•]. It is of note that this technique helps to resolve OSA only if pharyngeal collapse is limited to the retro palatal area. However, additional nonpalatal sites of upper airway obstruction are present in most of the obese OSA patients [153]. As a result, in most of the studies, the effectiveness of UPPP varies, showing only 50 $\%$ success rate (definition of success was $50 \%$ reduction in AHI after surgery) in non obese, mild to moderate sleep apnea patients $[150,153,154]$. Moreover, not only the efficacy of UPPP seems to diminish over time [155], but UPPP is also significantly less effective than the MADs [155]. In addition, those patients who undergo UPPP surgery are more at risk of CPAP noncompliance due to increase leaks and mouth dryness after surgery [156]. Therefore, the use of UPPP is not currently recommended, especially in OSA patients with multiple sites of airway obstruction.

\section{Laser-assisted uvulopalatoplasty (LAUP)}

Like UPPP this technique is being used to reduce soft palate redundancy. LAUP is an office-based surgical procedure that progressively shortens and tightens the uvula and palate through a series of carbon dioxide laser incisions and vaporizations [150]. However this method did not demonstrate any significant effect on severity of disease or symptoms $[157,158]$ and might even worsen sleep-disordered breathing. As a result, LAUP is not recommended as a treatment for OSA [159].

Radiofrequency surgery of the soft palate

This method employs radiofrequency technique to excise palatal tissue. Several studies demonstrated that this minimally invasive surgery improves snoring and sleepiness 
$[144,145]$. Although snoring typically cannot be eliminated completely, the procedure is a safe and effective method to improve snoring. However, the data concerning OSA is limited and no randomized controlled trials are available in sleep apnea. Therefore it cannot be recommended as a sole therapy in obstructive sleep apnea subjects.

\section{Uvulopalatal flap}

The uvulopalatal flap is conducted to reduce the volume of the palate to open the airway. This is a modified version of UPPP with similar complications. The uvulopalatal flap is created by removal of the oral mucosa and salivatory glands, and bilateral incisions into the posterior pillar. This flap is rotated upwards and sutured into the defect [160]. The main disadvantage of this technique compared to UPPP is that despite preservation of all muscles no visible uvula is left to act as a lubricating structure for the palate. Both UPPP and the flap showed comparable results in term of effectiveness to treat OSA, amount of tissue removed and complications [160]. Studies that have investigated the efficacy of uvulopalatal flap with tonsillectomy for OSA have shown a significant improvement of the severity of OSA and quality of life [161-167]. However, it has to be kept in mind that surgical success rates decrease with increasing BMI and AHI in general [168]. Due to a lack of evidence, uvulopalatal flaps are not recommended to treat simple snoring, but can be appropriate for OSA in patients with palatal obstruction.

Soft palatal implants

This method involves implants which consist in inserting three 18-millimeter polyethylene terephthalate fibers within the muscular layer of the soft palate at the hard palate junction with a distance of $3 \mathrm{~mm}$ from each other under local anesthesia [169]. The fibers induce a chronic inflammatory response that creates a fibrous capsule around the implants. This inflammatory reaction is designed to reduce the soft palate flutter and collapsibility that contribute to sleep-disordered breathing at the velopharyngeal level [170]. There are conflicting reports regarding the efficacy of pillar implants. Some authors reported improvement in AHI post operatively as well as 3-15 months after surgery [171-174]. But others found no significant change in AHI [169]. A recent study showed that pillar implants may subjectively improve CPAP satisfaction, but failed to show any improvement in the compliance of CPAP or in reduction of CPAP pressure [175]. Therefore, pillar implants cannot be recommended and may only be considered in patients with mild to moderate OSA who cannot tolerate or failed other conservative approaches.
Radiofrequency surgery of the tongue base

This method employs interstitial radiofrequency surgery of the tongue base using a temperature-controlled device. Long-term studies have demonstrated relapse of OSA (AHI has increased) [176]. Therefore, radiofrequency surgery of the tongue cannot generally be recommended as an isolated or combined procedure and may only be considered in selected patients with mild to moderate sleep apnea intolerant to conservative treatment, as long as the overall condition appears suitable (non or only moderately, obese patients with retro-lingual obstruction).

\section{Hyoid suspension}

This procedure, first described by Riley et al. in 1986, aims at advancement of the hyoid bone and subsequent increase in the retro-lingual space [177] to avoid the back positioning of the tongue during sleep. Studies that investigated the effect of an isolated hyoid suspension for OSA showed decreased AHI but not complete resolution. There is no controlled trial to compare this technique with CPAP therapy. Therefore, hyoid suspension may be considered as a modality only in combination with other procedures or in case of CPAP failure. It is important to keep in mind that surgical success rates decrease with increasing BMI and AHI [178-180]. Due to a lack of evidence, hyoid suspension is not recommended for simple snoring.

Partial tongue base resection

There are several surgical techniques and procedures including laser midline glossectomy, tongue base reduction with hyoepiglottoplasty, lingualplasty, lingual tonsillectomy, palatopharyngoglossoplasty, uvulopalatopharyngoglossoplasty, glossopexia, and tongue base suspension. At the present time, tongue base soft tissue procedures cannot be recommended as a single treatment option for obese patients with moderate to severe OSA. There are currently no data to support their role in patients with mild disease.

\section{Maxillomandibular advancement (MMA)}

Maxillomandibular advancement (MMA) is a multilevel skeletal surgery, which aims to improve hypopharyngeal or tongue base obstruction in order to enlarge the retrolingual and retropalatal airway. It pulls forward the anterior pharyngeal tissues attached to the maxilla, mandible, and hyoid to structurally enlarge the entire velo-orohypopharyngeal airway, and enhances the neuromuscular tone of the pharyngeal dilator musculature [181]. The success rate varied between $67 \%$ and $100 \%$ among studies [181-183]. MMA is perhaps the most effective surgery for improving OSA 
when performed on appropriately selected patients. Although highly successful in improving polysomnographic outcomes, the clinical role of maxillofacial surgery remains unclear. Therefore, MMA is recommended in selected group of young, non obese patients who refuse CPAP treatment $[85 \bullet \cdot]$. However, essential benefit should be weighed against the risk of complications and future studies need to identify proper candidates for this surgery.

\section{Multilevel surgery}

When the obstruction site is indefinite or multiple, multilevel surgery offers greater overall success rates than uvulopalatopharyngoplasty (UPPP) or genioglossal advancement alone [184-187]. Many OSA patients have narrowing of multiple sites in the upper airway, at the nasal, retropalatal, and hypopharyngeal level. The surgery aims to correct anatomical abnormalities in the upper airway to avoid upper airway collapse during sleep. However, multilevel surgery cannot be recommended as a substitute for CPAP but only as a salvage procedure for OSA patients in whom CPAP and other conservative therapies have failed. Surgical success of multi-level surgery for OSA is often unpredictable and less effective than CPAP [188]. It also seems to be more effective in mild to moderate REM-associated OSA, in patients age $<60$ years, and with BMI $<30 \mathrm{~kg} / \mathrm{m}-2$, pharyngeal narrowing in the basal lingual area, or retrognathia [189-191]. Success depends on appropriate patient selection, the type of surgical procedure performed, and the experience of the surgeon. Most studies are retrospective and observational case series, and therefore do not provide high-level evidence.

\section{Conclusions}

Lifestyle modifications such as weight loss, avoidance of alcohol, and positional therapy might be beneficial to improve upper airway patency. However, the main therapeutic options include CPAP therapy, oral appliances, and surgical procedures. For most individuals, CPAP remains the preferable and most effective first-line treatment for OSA. However, a significant proportion of patients are unable to tolerate CPAP therapy and seek alternate treatment. MADs seems to be effective in the clinical management of snoring and mild OSA, although ongoing research is essential to better define clinical outcomes, as well as its long-term effectiveness and adverse effects. Upper airway surgery is generally reserved as a salvage treatment for patients with moderate to severe OSA who have failed a trial of CPAP therapy. Many surgical options are not curative for sleep-disordered breathing but maxillomandibular advancement is overall safe and effective. Nevertheless, many sleep physicians are reluctant to refer patients for surgery because its short-term and long-term risks have not been fully evaluated and may hamper compliance with subsequent CPAP therapy.

An improved characterization of the different phenotypes of OSA, coupled with more systematic long-term therapeutic trials may allow to tailor the most appropriate treatment modality for sleep-disordered breathing on an individual basis. For the present, CPAP therapy still remains the best therapeutic option despite its limitations.

Disclosure No potential conflicts of interest relevant to this article were reported.

\section{References}

Papers of particular interest, published recently, have been highlighted as:

- Of importance

-. Of major importance

1. Bradford A, McGuire M, O'Halloran KD. Does episodic hypoxia affect upper airway dilator muscle function? Implications for the pathophysiology of obstructive sleep apnoea. Respir Physiol Neurobiol. 2005;147(2-3):223-34.

2. Young T, Palta M, Dempsey J, Skatrud J, Weber S, Badr S. The occurrence of sleep-disordered breathing among middle-aged adults. N Engl J Med. 1993;328:1230-5.

3. Young T, Peppard PE, Gottlieb DJ. Epidemiology of obstructive sleep apnea: a population health perspective. Am J Respir Crit Care Med. 2002;165:1217-39.

4. Peppard PE, Young T, Palta M, Skatrud J. Prospective study of the association between sleep-disordered breathing and hypertension. N Engl J Med. 2000;342:1378-84.

5. Peker Y, Kraiczi H, Hedner J, Loth S, Johansson A, Bende M. An independent association between obstructive sleep apnoea and coronary artery disease. Eur Respir J. 1999;14:179-84.

6. Yaggi HK, Concato J, Kernan WN, Lichtman JH, Brass LM, Mohsenin V. Obstructive sleep apnea as a risk factor for stroke and death. N Engl J Med. 2005;353:2034-41.

7. Mohsenin V. Effects of gender on upper airway collapsibility and severity of obstructive sleep apnea. Sleep Med. 2003;4:523-9.

8. Schwab RJ, Gupta KB, Gefter WB, Metzger LJ, Hoffman EA, Pack AI. Upper airway and soft tissue anatomy in normal subjects and patients with sleep-disordered breathing. Significance of the lateral pharyngeal walls. Am J Respir Crit Care Med. 1995;152: 1673-89.

9. Jordan AS, White DP. Pharyngeal motor control and the pathogenesis of obstructive sleep apnea. Respir Physiol Neurobiol. 2008;160:1-7.

10. Hoffstein V, Zamel N, Phillipson EA. Lung volume dependence of pharyngeal cross-sectional area in patients with obstructive sleep apnea. Am Rev Respir Dis. 1984;130:175-8.

11. Rubinstein I, Hoffstein V, Bradley TD. Lung volume-related changes in the pharyngeal area of obese females with and without obstructive sleep apnoea. Eur Respir J. 1989;2:344-51.

12. Navajas D, Farre R, Rotger MM, Milic-Emili J, Sanchis J. Effect of body posture on respiratory impedance. J Appl Physiol. 1988;64:194-9. 
13. Strobel RJ, Rosen RC. Obesity and weight loss in obstructive sleep apnea: a critical review. Sleep. 1996;19:104-15.

14. Sullivan CE, Issa FG, Berthon-Jones M, Eves L. Reversal of obstructive sleep apnoea by continuous positive airway pressure applied through the nares. Lancet. 1981;1:862-5.

15. Cartwright RD. Effect of sleep position on sleep apnea severity. Sleep. 1984;7:110-4.

16. George CF, Millar TW, Kryger MH. Sleep apnea and body position during sleep. Sleep. 1988;11:90-9.

17. McEvoy RD, Sharp DJ, Thornton AT. The effects of posture on obstructive sleep apnea. Am Rev Respir Dis. 1986;133:662-6.

18. Petruson B. Improvement of the nasal airflow by the nasal dilator Nozovent. Rhinology. 1988;26:289-92.

19. Phillips BA, Okeson J, Paesani D, Gilmore R. Effect of sleep position on sleep apnea and parafunctional activity. Chest. 1986;90:424-9.

20. Issa FG, Sullivan CE. Upper airway closing pressures in obstructive sleep apnea. J Appl Physiol. 1984;57:520-7.

21. Shepard Jr JW, Burger CD. Nasal and oral flow-volume loops in normal subjects and patients with obstructive sleep apnea. Am Rev Respir Dis. 1990;142:1288-93.

22. Pevernagie DA, Stanson AW, Sheedy 2nd PF, Daniels BK, Shepard Jr JW. Effects of body position on the upper airway of patients with obstructive sleep apnea. Am J Respir Crit Care Med. 1995;152: 179-85.

23. Chan AS, Lee RW, Cistulli PA. Non-positive airway pressure modalities: mandibular advancement devices/positional therapy. Proc Am Thorac Soc. 2008;5:179-84.

24. Richard W, Kox D, den Herder C, Laman M, van Tinteren H, de Vries N. The role of sleep position in obstructive sleep apnea syndrome. Eur Arch Otorhinolaryngol. 2006;263:946-50.

25. Oksenberg A, Silverberg DS, Arons E, Radwan H. Positional vs nonpositional obstructive sleep apnea patients: anthropomorphic, nocturnal polysomnographic, and multiple sleep latency test data. Chest. 1997;112:629-39.

26. Lindberg E, Elmasry A, Gislason T, Janson C, Bengtsson H, Hetta J, Nettelbladt M, Boman G. Evolution of sleep apnea syndrome in sleepy snorers: a population-based prospective study. Am J Respir Crit Care Med. 1999;159:2024-7.

27. Pendlebury ST, Pepin JL, Veale D, Levy P. Natural evolution of moderate sleep apnoea syndrome: significant progression over a mean of 17 months. Thorax. 1997;52:872-8.

28. Maurer JT, Stuck BA, Hein G, Verse T, Hormann K. Treatment of obstructive sleep apnea with a new vest preventing the supine position. Dtsch Med Wochenschr. 2003;128:71-5.

29. Zuberi NA, Rekab K, Nguyen HV. Sleep apnea avoidance pillow effects on obstructive sleep apnea syndrome and snoring. Sleep Breath. 2004;8:201-7.

30. Cartwright R, Ristanovic R, Diaz F, Caldarelli D, Alder G. A comparative study of treatments for positional sleep apnea. Sleep. 1991;14:546-52.

31. Cartwright RD, Lloyd S, Lilie J, Kravitz H. Sleep position training as treatment for sleep apnea syndrome: a preliminary study. Sleep. 1985;8:87-94.

32. Wenzel S, Smith E, Leiacker R, Fischer Y. Efficacy and longterm compliance of the vest preventing the supine position in patients with obstructive sleep apnea. Laryngorhinootologie. 2007;86:579-83.

33. Loord H, Hultcrantz E. Positioner-a method for preventing sleep apnea. Acta Otolaryngol. 2007;127:861-8.

34. Berger M, Oksenberg A, Silverberg DS, Arons E, Radwan H, Iaina A. Avoiding the supine position during sleep lowers $24 \mathrm{~h}$ blood pressure in obstructive sleep apnea (OSA) patients. J Hum Hypertens. 1997;11:657-64.

35. Skinner MA, Kingshott RN, Jones DR, Homan SD, Taylor DR. Elevated posture for the management of obstructive sleep apnea. Sleep Breath. 2004;8:193-200.
36. Heinzer RC, Pellaton C, Rey V, Rossetti AO, Lecciso G, HabaRubio J, Tafti M, and Lavigne G. Positional therapy for obstructive sleep apnea: An objective measurement of patients' usage and efficacy at home. Sleep Med. 2012.

37. Schwartz AR, Patil SP, Laffan AM, Polotsky V, Schneider H, Smith PL. Obesity and obstructive sleep apnea: pathogenic mechanisms and therapeutic approaches. Proc Am Thorac Soc. 2008;5:185-92.

38. Sutherland K, Lee RW, Phillips CL, Dungan G, Yee BJ, Magnussen JS, Grunstein RR, Cistulli PA. Effect of weight loss on upper airway size and facial fat in men with obstructive sleep apnoea. Thorax. 2011;66:797-803.

39. Shelton KE, Woodson H, Gay S, Suratt PM. Pharyngeal fat in obstructive sleep apnea. Am Rev Respir Dis. 1993;148:462-6.

40. Oliven A, Aspandiarov E, Gankin I, Gaitini L, Tov N. Collapsibility of the relaxed pharynx and risk of sleep apnoea. Eur Respir J. 2008;32:1309-15.

41. Schwartz AR, Gold AR, Schubert N, Stryzak A, Wise RA, Permutt S, Smith PL. Effect of weight loss on upper airway collapsibility in obstructive sleep apnea. Am Rev Respir Dis. 1991;144:494-8.

42. Hernandez TL, Ballard RD, Weil KM, Shepard TY, Scherzinger AL, Stamm ER, Sharp TA, Eckel RH. Effects of maintained weight loss on sleep dynamics and neck morphology in severely obese adults. Obesity (Silver Spring). 2009;17:84-91.

43. Sugerman HJ, Fairman RP, Sood RK, Engle K, Wolfe L, Kellum JM. Long-term effects of gastric surgery for treating respiratory insufficiency of obesity. Am J Clin Nutr. 1992;55:597S-601.

44. Yee BJ, Phillips CL, Banerjee D, Caterson I, Hedner JA, Grunstein RR. The effect of sibutramine-assisted weight loss in men with obstructive sleep apnoea. Int J Obes (Lond). 2007;31:161-8.

45. Ferland A, Poirier P, Series F. Sibutramine versus continuous positive airway pressure in obese obstructive sleep apnoea patients. Eur Respir J. 2009;34:694-701.

46. Phillips CL, Yee BJ, Trenell MI, Magnussen JS, Wang D, Banerjee D, Berend N, Grunstein RR. Changes in regional adiposity and cardio-metabolic function following a weight loss program with sibutramine in obese men with obstructive sleep apnea. J Clin Sleep Med. 2009;5:416-21.

47. Lettieri CJ, Eliasson AH, Greenburg DL. Persistence of obstructive sleep apnea after surgical weight loss. J Clin Sleep Med. 2008;4:333-8.

48. Lojander J, Mustajoki P, Ronka S, Mecklin P, Maasilta P. A nurse-managed weight reduction programme for obstructive sleep apnoea syndrome. J Intern Med. 1998;244:251-5.

49. Kajaste S, Brander PE, Telakivi T, Partinen M, Mustajoki P. A cognitive-behavioral weight reduction program in the treatment of obstructive sleep apnea syndrome with or without initial nasal CPAP: a randomized study. Sleep Med. 2004;5:125-31.

50. Rasheid S, Banasiak M, Gallagher SF, Lipska A, Kaba S, Ventimiglia $\mathrm{D}$, Anderson WM, Murr MM. Gastric bypass is an effective treatment for obstructive sleep apnea in patients with clinically significant obesity. Obes Surg. 2003;13:58-61.

51. Busetto L, Enzi G, Inelmen EM, Costa G, Negrin V, Sergi G, Vianello A. Obstructive sleep apnea syndrome in morbid obesity: effects of intragastric balloon. Chest. 2005;128:618-23.

52. Charuzi I, Fraser D, Peiser J, Ovnat A, Lavie P. Sleep apnea syndrome in the morbidly obese undergoing bariatric surgery. Gastroenterol Clin North Am. 1987;16:517-9.

53. Valencia-Flores M, Orea A, Herrera M, Santiago V, Rebollar V, Castano VA, Oseguera J, Pedroza J, Sumano J, Resendiz M, et al. Effect of bariatric surgery on obstructive sleep apnea and hypopnea syndrome, electrocardiogram, and pulmonary arterial pressure. Obes Surg. 2004;14:755-62.

54. Peppard PE, Young T, Palta M, Dempsey J, Skatrud J. Longitudinal study of moderate weight change and sleep-disordered breathing. JAMA. 2000;284:3015-21. 
55. Johansson K, Neovius M, Lagerros YT, Harlid R, Rossner S, Granath F, Hemmingsson E. Effect of a very low energy diet on moderate and severe obstructive sleep apnoea in obese men: a randomised controlled trial. BMJ. 2009;339:b4609.

56. Chan AS, Sutherland K, Schwab RJ, Zeng B, Petocz P, Lee RW, Darendeliler MA, Cistulli PA. The effect of mandibular advancement on upper airway structure in obstructive sleep apnoea. Thorax. 2010;65:726-32.

57. Kyung SH, Park YC, Pae EK. Obstructive sleep apnea patients with the oral appliance experience pharyngeal size and shape changes in three dimensions. Angle Orthod. 2005;75:15-22.

58. Ng AT, Gotsopoulos H, Qian J, Cistulli PA. Effect of oral appliance therapy on upper airway collapsibility in obstructive sleep apnea. Am J Respir Crit Care Med. 2003;168:238-41.

59. Ferguson KA, Cartwright R, Rogers R, Schmidt-Nowara W. Oral appliances for snoring and obstructive sleep apnea: a review. Sleep. 2006;29:244-62.

60. Hans MG, Nelson S, Luks VG, Lorkovich P, Baek SJ. Comparison of two dental devices for treatment of obstructive sleep apnea syndrome (OSAS). Am J Orthod Dentofacial Orthop. 1997;111:562-70.

61. Gotsopoulos H, Chen C, Qian J, Cistulli PA. Oral appliance therapy improves symptoms in obstructive sleep apnea: a randomized, controlled trial. Am J Respir Crit Care Med. 2002;166:743-8.

62. Barnes M, McEvoy RD, Banks S, Tarquinio N, Murray CG, Vowles N, Pierce RJ. Efficacy of positive airway pressure and oral appliance in mild to moderate obstructive sleep apnea. Am J Respir Crit Care Med. 2004;170:656-64.

63. Naismith SL, Winter VR, Hickie IB, Cistulli PA. Effect of oral appliance therapy on neurobehavioral functioning in obstructive sleep apnea: a randomized controlled trial. J Clin Sleep Med. 2005;1:374-80.

64. Petri N, Svanholt P, Solow B, Wildschiodtz G, Winkel P. Mandibular advancement appliance for obstructive sleep apnoea: results of a randomised placebo controlled trial using parallel group design. J Sleep Res. 2008;17:221-9.

65. Ferguson KA, Ono T, Lowe AA, Al-Majed S, Love LL, Fleetham JA. A short-term controlled trial of an adjustable oral appliance for the treatment of mild to moderate obstructive sleep apnoea. Thorax. 1997;52:362-8.

66. Randerath WJ, Heise M, Hinz R, Ruehle KH. An individually adjustable oral appliance vs continuous positive airway pressure in mild-to-moderate obstructive sleep apnea syndrome. Chest. 2002;122:569-75

67. Tan YK, L'Estrange PR, Luo YM, Smith C, Grant HR, Simonds AK, Spiro SG, Battagel JM. Mandibular advancement splints and continuous positive airway pressure in patients with obstructive sleep apnoea: a randomized cross-over trial. Eur J Orthod. 2002;24:239-49.

68. Hoekema A, Stegenga B, Wijkstra PJ, van der Hoeven JH, Meinesz AF, de Bont LG. Obstructive sleep apnea therapy. J Dent Res. 2008;87:882-7.

69. Gagnadoux F, Fleury B, Vielle B, Petelle B, Meslier N, N'Guyen XL, Trzepizur W, Racineux JL. Titrated mandibular advancement versus positive airway pressure for sleep apnoea. Eur Respir J. 2009;34:914-20.

70. Engleman HM, McDonald JP, Graham D, Lello GE, Kingshott RN, Coleman EL, Mackay TW, Douglas NJ. Randomized crossover trial of two treatments for sleep apnea/hypopnea syndrome: continuous positive airway pressure and mandibular repositioning splint. Am J Respir Crit Care Med. 2002;166:855-9.

71. Ferguson KA, Ono T, Lowe AA, Keenan SP, Fleetham JA. A randomized crossover study of an oral appliance vs nasalcontinuous positive airway pressure in the treatment of mildmoderate obstructive sleep apnea. Chest. 1996;109:1269-75.
72. Lam B, Sam K, Mok WY, Cheung MT, Fong DY, Lam JC, Lam DC, Yam LY, Ip MS. Randomised study of three non-surgical treatments in mild to moderate obstructive sleep apnoea. Thorax. 2007;62:354-9.

73. Gauthier L, Laberge L, Beaudry M, Laforte M, Rompre PH, Lavigne GJ. Efficacy of two mandibular advancement appliances in the management of snoring and mild-moderate sleep apnea: a cross-over randomized study. Sleep Med. 2009;10:329-36.

74. Gotsopoulos H, Kelly JJ, Cistulli PA. Oral appliance therapy reduces blood pressure in obstructive sleep apnea: a randomized, controlled trial. Sleep. 2004;27:934-41.

75. Coruzzi P, Gualerzi M, Bernkopf E, Brambilla L, Brambilla V, Broia V, Lombardi C, Parati G. Autonomic cardiac modulation in obstructive sleep apnea: effect of an oral jaw-positioning appliance. Chest. 2006;130:1362-8.

76. Itzhaki S, Dorchin H, Clark G, Lavie L, Lavie P, Pillar G. The effects of 1-year treatment with a herbst mandibular advancement splint on obstructive sleep apnea, oxidative stress, and endothelial function. Chest. 2007;131:740-9.

77. Trzepizur W, Gagnadoux F, Abraham P, Rousseau P, Meslier N, Saumet JL, Racineux JL. Microvascular endothelial function in obstructive sleep apnea: Impact of continuous positive airway pressure and mandibular advancement. Sleep Med. 2009;10: 746-52.

78. Hoekema A, Voors AA, Wijkstra PJ, Stegenga B, van der Hoeven JH, Tol CG, de Bont LG. Effects of oral appliances and CPAP on the left ventricle and natriuretic peptides. Int J Cardiol. 2008; 128:232-9.

79. Hoekema A, Stegenga B, Bakker M, Brouwer WH, de Bont LG, Wijkstra PJ, van der Hoeven JH. Simulated driving in obstructive sleep apnoea-hypopnoea; effects of oral appliances and continuous positive airway pressure. Sleep Breath. 2007;11:129-38.

80. Mehta A, Qian J, Petocz P, Darendeliler MA, Cistulli PA. A randomized, controlled study of a mandibular advancement splint for obstructive sleep apnea. Am J Respir Crit Care Med. 2001; 163:1457-61.

81. Johnston CD, Gleadhill IC, Cinnamond MJ, Gabbey J, Burden DJ. Mandibular advancement appliances and obstructive sleep apnoea: a randomized clinical trial. Eur J Orthod. 2002;24:251-62.

82. Walker-Engstrom ML, Ringqvist I, Vestling O, Wilhelmsson B, Tegelberg A. A prospective randomized study comparing two different degrees of mandibular advancement with a dental appliance in treatment of severe obstructive sleep apnea. Sleep Breath. 2003;7:119-30.

83. Marklund M, Stenlund H, Franklin KA. Mandibular advancement devices in 630 men and women with obstructive sleep apnea and snoring: tolerability and predictors of treatment success. Chest. 2004;125:1270-8.

84. Liu Y, Lowe AA, Fleetham JA, Park YC. Cephalometric and physiologic predictors of the efficacy of an adjustable oral appliance for treating obstructive sleep apnea. Am J Orthod Dentofacial Orthop. 2001;120:639-47.

85. • Randerath WJ, Verbraecken J, Andreas S, Bettega G, Boudewyns A, Hamans E, Jalbert F, Paoli JR, Sanner B, Smith I, et al. NonCPAP therapies in obstructive sleep apnoea. Eur Respir J 2011;37:1000-1028. Major ERS guidelines with an overview of evidence for non-CPAP therapy of OSA.

86. Petit FX, Pepin JL, Bettega G, Sadek H, Raphael B, Levy P. Mandibular advancement devices: rate of contraindications in 100 consecutive obstructive sleep apnea patients. Am J Respir Crit Care Med. 2002;166:274-8.

87. Vanderveken OM, Devolder A, Marklund M, Boudewyns AN, Braem MJ, Okkerse W, Verbraecken JA, Franklin KA, De Backer WA, Van de Heyning PH. Comparison of a custom-made and a thermoplastic oral appliance for the treatment of mild sleep apnea. Am J Respir Crit Care Med. 2008;178:197-202. 
88. Fleury B, Rakotonanahary D, Petelle B, Vincent G, Pelletier Fleury N, Meyer B, Lebeau B. Mandibular advancement titration for obstructive sleep apnea: optimization of the procedure by combining clinical and oximetric parameters. Chest. 2004;125: 1761-7.

89. Kato J, Isono S, Tanaka A, Watanabe T, Araki D, Tanzawa H, Nishino T. Dose-dependent effects of mandibular advancement on pharyngeal mechanics and nocturnal oxygenation in patients with sleep-disordered breathing. Chest. 2000;117:1065-72.

90. Dort LC, Hadjuk E, Remmers JE. Mandibular advancement and obstructive sleep apnoea: a method for determining effective mandibular protrusion. Eur Respir J. 2006;27:1003-9.

91. Bloch KE, Iseli A, Zhang JN, Xie X, Kaplan V, Stoeckli PW, Russi EW. A randomized, controlled crossover trial of two oral appliances for sleep apnea treatment. Am J Respir Crit Care Med. 2000;162:246-51.

92. Dort L, Brant R. A randomized, controlled, crossover study of a noncustomized tongue retaining device for sleep disordered breathing. Sleep Breath. 2008;12:369-73.

93. Deane SA, Cistulli PA, Ng AT, Zeng B, Petocz P, Darendeliler MA. Comparison of mandibular advancement splint and tongue stabilizing device in obstructive sleep apnea: a randomized controlled trial. Sleep. 2009;32:648-53.

94. Barthlen GM, Brown LK, Wiland MR, Sadeh JS, Patwari J, Zimmerman M. Comparison of three oral appliances for treatment of severe obstructive sleep apnea syndrome. Sleep Med. 2000;1:299-305.

95. Higurashi N, Kikuchi M, Miyazaki S, Itasaka Y. Effectiveness of a tongue-retaining device. Psychiatry Clin Neurosci. 2002;56: $331-2$.

96. Remmers JE, deGroot WJ, Sauerland EK, Anch AM. Pathogenesis of upper airway occlusion during sleep. J Appl Physiol. 1978;44:931-8.

97. Dempsey JA, Veasey SC, Morgan BJ, O’Donnell CP. Pathophysiology of sleep apnea. Physiol Rev. 2010;90:47-112.

98. Schwartz AR, Eisele DW, Hari A, Testerman R, Erickson D, Smith PL. Electrical stimulation of the lingual musculature in obstructive sleep apnea. J Appl Physiol. 1996;81:643-52.

99. Mann EA, Burnett T, Cornell S, Ludlow CL. The effect of neuromuscular stimulation of the genioglossus on the hypopharyngeal airway. Laryngoscope. 2002;112:351-6.

100. Oliven A, O'Hearn DJ, Boudewyns A, Odeh M, De Backer W, van de Heyning P, Smith PL, Eisele DW, Allan L, Schneider H, et al. Upper airway response to electrical stimulation of the genioglossus in obstructive sleep apnea. J Appl Physiol. 2003;95: 2023-9.

101. Oliven A, Schnall RP, Pillar G, Gavriely N, Odeh M. Sublingual electrical stimulation of the tongue during wakefulness and sleep. Respir Physiol. 2001;127:217-26.

102. Oliven A, Tov N, Geitini L, Steinfeld U, Oliven R, Schwartz AR, Odeh M. Effect of genioglossus contraction on pharyngeal lumen and airflow in sleep apnoea patients. Eur Respir J. 2007;30:748-58.

103. Isono S, Tanaka A, Nishino T. Effects of tongue electrical stimulation on pharyngeal mechanics in anaesthetized patients with obstructive sleep apnoea. Eur Respir J. 1999;14:1258-65.

104. Miki H, Hida W, Chonan T, Kikuchi Y, Takishima T. Effects of submental electrical stimulation during sleep on upper airway patency in patients with obstructive sleep apnea. Am Rev Respir Dis. 1989;140:1285-9.

105. Guilleminault C, Powell N, Bowman B, Stoohs R. The effect of electrical stimulation on obstructive sleep apnea syndrome. Chest. 1995;107:67-73.

106. Decker MJ, Haaga J, Arnold JL, Atzberger D, Strohl KP. Functional electrical stimulation and respiration during sleep. J Appl Physiol. 1993;75:1053-61.
107. Eastwood PR, Barnes M, Walsh JH, Maddison KJ, Hee G, Schwartz AR, Smith PL, Malhotra A, McEvoy RD, Wheatley JR, et al. Treating obstructive sleep apnea with hypoglossal nerve stimulation. Sleep. 2011;34:1479-86.

108. Verse T, Schwalb J, Hormann K, Stuck BA, Maurer JT. Submental transcutaneous electrical stimulation for obstructive sleep apnea. HNO. 2003;51:966-70.

109. Randerath WJ, Galetke W, Domanski U, Weitkunat R, Ruhle KH. Tongue-muscle training by intraoral electrical neurostimulation in patients with obstructive sleep apnea. Sleep. 2004;27:254-9.

110. Brownell LG, West P, Sweatman P, Acres JC, Kryger MH. Protriptyline in obstructive sleep apnea: a double-blind trial. N Engl J Med. 1982;307:1037-42.

111. Berry RB, Yamaura EM, Gill K, Reist C. Acute effects of paroxetine on genioglossus activity in obstructive sleep apnea. Sleep. 1999;22:1087-92.

112. Carley DW, Olopade C, Ruigt GS, Radulovacki M. Efficacy of mirtazapine in obstructive sleep apnea syndrome. Sleep. 2007; 30:35-41.

113. Hedner J, Kraiczi H, Peker Y, Murphy P. Reduction of sleepdisordered breathing after physostigmine. Am J Respir Crit Care Med. 2003;168:1246-51.

114. Jokic R, Klimaszewski A, Mink J, Fitzpatrick MF. Surface tension forces in sleep apnea: the role of a soft tissue lubricant: a randomized double-blind, placebo-controlled trial. Am J Respir Crit Care Med. 1998;157:1522-5.

115. Hellgren J, Omenaas E, Gislason T, Jogi R, Franklin KA, Lindberg E, Janson C, Toren K. Perennial non-infectious rhinitis-an independent risk factor for sleep disturbances in Asthma. Respir Med. 2007;101:1015-20.

116. Canova CR, Downs SH, Knoblauch A, Andersson M, Tamm M, Leuppi JD. Increased prevalence of perennial allergic rhinitis in patients with obstructive sleep apnea. Respiration. 2004;71:138-43.

117. Zhang L, Mendoza-Sassi RA, Cesar JA, and Chadha NK. Intranasal corticosteroids for nasal airway obstruction in children with moderate to severe adenoidal hypertrophy. Cochrane Database Syst Rev 2008;CD006286.

118. Craig TJ, Mende C, Hughes K, Kakumanu S, Lehman EB, Chinchilli $\mathrm{V}$. The effect of topical nasal fluticasone on objective sleep testing and the symptoms of rhinitis, sleep, and daytime somnolence in perennial allergic rhinitis. Allergy Asthma Proc. 2003;24:53-8.

119. Kiely JL, Nolan P, McNicholas WT. Intranasal corticosteroid therapy for obstructive sleep apnoea in patients with co-existing rhinitis. Thorax. 2004;59:50-5.

120. Clarenbach CF, Kohler M, Senn O, Thurnheer R, Bloch KE. Does nasal decongestion improve obstructive sleep apnea? J Sleep Res. 2008;17:444-9.

121. McNicholas WT, Tarlo S, Cole P, Zamel N, Rutherford R, Griffin D, Phillipson EA. Obstructive apneas during sleep in patients with seasonal allergic rhinitis. Am Rev Respir Dis. 1982;126:625-8.

122. Metes A, Cole P, Hoffstein V, Miljeteig H. Nasal airway dilation and obstructed breathing in sleep. Laryngoscope. 1992;102:1053-5.

123. Hoijer U, Ejnell H, Hedner J, Petruson B, Eng LB. The effects of nasal dilation on snoring and obstructive sleep apnea. Arch Otolaryngol Head Neck Surg. 1992;118:281-4.

124. Schonhofer B, Franklin KA, Brunig H, Wehde H, Kohler D. Effect of nasal-valve dilation on obstructive sleep apnea. Chest. 2000;118:587-90.

125. - Kryger MH, Berry RB, and Massie CA. Long-term use of a nasal expiratory positive airway pressure (EPAP) device as a treatment for obstructive sleep apnea (OSA). J Clin Sleep Med 2011;7:449-453B. This study shows good results of using nasal EPAP in OSA patients.

126. Colrain IM, Brooks S, Black J. A pilot evaluation of a nasal expiratory resistance device for the treatment of obstructive sleep apnea. J Clin Sleep Med. 2008;4:426-33. 
127. Rosenthal L, Massie CA, Dolan DC, Loomas B, Kram J, Hart RW. A multicenter, prospective study of a novel nasal EPAP device in the treatment of obstructive sleep apnea: efficacy and 30-day adherence. J Clin Sleep Med. 2009;5:532-7.

128. Patel AV, Hwang D, Masdeu MJ, Chen GM, Rapoport DM, Ayappa I. Predictors of response to a nasal expiratory resistor device and its potential mechanisms of action for treatment of obstructive sleep apnea. J Clin Sleep Med. 2011;7:13-22.

129. Berry RB, Kryger MH, Massie CA. A novel nasal expiratory positive airway pressure (EPAP) device for the treatment of obstructive sleep apnea: a randomized controlled trial. Sleep. 2011;34:479-85.

130. White DP, Cadieux RJ, Lombard RM, Bixler EO, Kales A, Zwillich CW. The effects of nasal anesthesia on breathing during sleep. Am Rev Respir Dis. 1985;132:972-5.

131. Basner RC, Simon PM, Schwartzstein RM, Weinberger SE, Weiss JW. Breathing route influences upper airway muscle activity in awake normal adults. J Appl Physiol. 1989;66: 1766-71.

132. Zwillich CW, Pickett C, Hanson FN, Weil JV. Disturbed sleep and prolonged apnea during nasal obstruction in normal men. Am Rev Respir Dis. 1981;124:158-60.

133. Lavie P, Fischel N, Zomer J, Eliaschar I. The effects of partial and complete mechanical occlusion of the nasal passages on sleep structure and breathing in sleep. Acta Otolaryngol. 1983;95: $161-6$.

134. Olsen KD, Kern EB, Westbrook PR. Sleep and breathing disturbance secondary to nasal obstruction. Otolaryngol Head Neck Surg. 1981;89:804-10.

135. Morris LG, Setlur J, Burschtin OE, Steward DL, Jacobs JB, Lee KC. Acoustic rhinometry predicts tolerance of nasal continuous positive airway pressure: a pilot study. Am J Rhinol. 2006;20: 133-7.

136. Choi JH, Kim EJ, Kim YS, Kim TH, Choi J, Kwon SY, Lee HM, Lee SH. Effectiveness of nasal surgery alone on sleep quality, architecture, position, and sleep-disordered breathing in obstructive sleep apnea syndrome with nasal obstruction. Am J Rhinol Allergy. 2011;25:338-41.

137. Zonato AI, Bittencourt LR, Martinho FL, Junior JF, Gregorio LC, Tufik S. Association of systematic head and neck physical examination with severity of obstructive sleep apnea-hypopnea syndrome. Laryngoscope. 2003;113:973-80.

138. Friedman M, Tanyeri H, La Rosa M, Landsberg R, Vaidyanathan K, Pieri S, Caldarelli D. Clinical predictors of obstructive sleep apnea. Laryngoscope. 1999;109:1901-7.

139. Shott SR. Evaluation and management of pediatric obstructive sleep apnea beyond tonsillectomy and adenoidectomy. Curr Opin Otolaryngol Head Neck Surg.

140. Martinho FL, Zonato AI, Bittencourt LR, Soares MC, Silva RF, Gregorio LC, Tufik S. Obese obstructive sleep apnea patients with tonsil hypertrophy submitted to tonsillectomy. Braz J Med Biol Res. 2006;39:1137-42.

141. Nakata S, Miyazaki S, Ohki M, Morinaga M, Noda A, Sugiura T, Sugiura M, Teranishi M, Katayama N, Nakashima T. Reduced nasal resistance after simple tonsillectomy in patients with obstructive sleep apnea. Am J Rhinol. 2007;21:192-5.

142. Powell NB, Riley RW, Troell RJ, Blumen MB, Guilleminault C. Radiofrequency volumetric reduction of the tongue. A porcine pilot study for the treatment of obstructive sleep apnea syndrome. Chest. 1997;111:1348-55.

143. Hukins CA, Mitchell IC, Hillman DR. Radiofrequency tissue volume reduction of the soft palate in simple snoring. Arch Otolaryngol Head Neck Surg. 2000;126:602-6.

144. Stuck BA, Sauter A, Hormann K, Verse T, Maurer JT. Radiofrequency surgery of the soft palate in the treatment of snoring. A placebo-controlled trial. Sleep. 2005;28:847-50.
145. Amoros-Sebastia LI. Radiofrequency treatment in simple snoring: tolerance, safety and results. Acta Otorrinolaringol Esp. 2011;62:300-5.

146. Nelson LM. Radiofrequency treatment for obstructive tonsillar hypertrophy. Arch Otolaryngol Head Neck Surg. 2000;126:73640.

147. Nelson LM. Temperature-controlled radiofrequency tonsil reduction: extended follow-up. Otolaryngol Head Neck Surg. 2001;125:456-61.

148. Friedman M, LoSavio P, Ibrahim H, Ramakrishnan V. Radiofrequency tonsil reduction: safety, morbidity, and efficacy. Laryngoscope. 2003;113:882-7.

149. Ericsson E, Hultcrantz E. Tonsil surgery in youths: good results with a less invasive method. Laryngoscope. 2007;117:654-61.

150. Won CH, Li KK, Guilleminault C. Surgical treatment of obstructive sleep apnea: upper airway and maxillomandibular surgery. Proc Am Thorac Soc. 2008;5:193-9.

151. Fujita S, Conway W, Zorick F, Roth T. Surgical correction of anatomic azbnormalities in obstructive sleep apnea syndrome: uvulopalatopharyngoplasty. Otolaryngol Head Neck Surg. 1981;89:923-34.

152. - Caples SM, Rowley JA, Prinsell JR, Pallanch JF, Elamin MB, Katz SG, and Harwick JD. Surgical modifications of the upper airway for obstructive sleep apnea in adults: a systematic review and meta-analysis. Sleep 2010;33:1396-1407. Meta-analysis of surgical treatment of OSA.

153. Sher AE. Upper airway surgery for obstructive sleep apnea. Sleep Med Rev. 2002;6:195-212.

154. Li HY, Wang PC, Lee LA, Chen NH, Fang TJ. Prediction of uvulopalatopharyngoplasty outcome: anatomy-based staging system versus severity-based staging system. Sleep. 2006;29: $1537-41$.

155. Walker-Engstrom ML, Tegelberg A, Wilhelmsson B, Ringqvist I. 4-year follow-up of treatment with dental appliance or uvulopalatopharyngoplasty in patients with obstructive sleep apnea: a randomized study. Chest. 2002;121:739-46.

156. Janson C, Noges E, Svedberg-Randt S, Lindberg E. What characterizes patients who are unable to tolerate continuous positive airway pressure (CPAP) treatment? Respir Med. 2000;94:145-9.

157. Ferguson KA, Heighway K, Ruby RR. A randomized trial of laser-assisted uvulopalatoplasty in the treatment of mild obstructive sleep apnea. Am J Respir Crit Care Med. 2003;167:15-9.

158. Larrosa F, Hernandez L, Morello A, Ballester E, Quinto L, Montserrat JM. Laser-assisted uvulopalatoplasty for snoring: does it meet the expectations? Eur Respir J. 2004;24:66-70.

159. Aurora RN, Casey KR, Kristo D, Auerbach S, Bista SR, Chowdhuri S, Karippot A, Lamm C, Ramar K, Zak R, et al. Practice parameters for the surgical modifications of the upper airway for obstructive sleep apnea in adults. Sleep. 2010;33:1408-13.

160. Powell N, Riley R, Guilleminault C, Troell R. A reversible uvulopalatal flap for snoring and sleep apnea syndrome. Sleep. 1996;19:593-9.

161. Neruntarat C. Uvulopalatal flap for snoring on an outpatient basis. Otolaryngol Head Neck Surg. 2003;129:353-9.

162. Neruntarat C. Genioglossus advancement and hyoid myotomy under local anesthesia. Otolaryngol Head Neck Surg. 2003; 129:85-91.

163. Li HY, Li KK, Chen NH, Wang CJ, Liao YF, Wang PC. Threedimensional computed tomography and polysomnography findings after extended uvulopalatal flap surgery for obstructive sleep apnea. Am J Otolaryngol. 2005;26:7-11.

164. Li HY, Huang YS, Chen NH, Fang TJ, Liu CY, Wang PC. Mood improvement after surgery for obstructive sleep apnea. Laryngoscope. 2004;114:1098-102.

165. Li HY, Chen NH, Shu YH, Wang PC. Changes in quality of life and respiratory disturbance after extended uvulopalatal flap 
surgery in patients with obstructive sleep apnea. Arch Otolaryngol Head Neck Surg. 2004;130:195-200.

166. Li HY, Chen NH, Lee LA, Shu YH, Fang TJ, Wang PC. Use of morphological indicators to predict outcomes of palatopharyngeal surgery in patients with obstructive sleep apnea. ORL J Otorhinolaryngol Relat Spec. 2004;66:119-23.

167. Li HY, Li KK, Chen NH, Wang PC. Modified uvulopalatopharyngoplasty: The extended uvulopalatal flap. Am J Otolaryngol. 2003;24:311-6.

168. Neruntarat C. Long-term results of palatal implants for obstructive sleep apnea. Eur Arch Otorhinolaryngol. 2011;268:1077-80.

169. Steward DL, Huntley TC, Woodson BT, Surdulescu V. Palate implants for obstructive sleep apnea: multi-institution, randomized, placebo-controlled study. Otolaryngol Head Neck Surg. 2008;139:506-10.

170. Ho WK, Wei WI, Chung KF. Managing disturbing snoring with palatal implants: a pilot study. Arch Otolaryngol Head Neck Surg. 2004;130:753-8.

171. Friedman M, Schalch P, Lin HC, Kakodkar KA, Joseph NJ, Mazloom N. Palatal implants for the treatment of snoring and obstructive sleep apnea/hypopnea syndrome. Otolaryngol Head Neck Surg. 2008;138:209-16.

172. Nordgard S, Hein G, Stene BK, Skjostad KW, Maurer JT. One-year results: palatal implants for the treatment of obstructive sleep apnea. Otolaryngol Head Neck Surg. 2007; 136:818-22.

173. Friedman M, Schalch P, Joseph NJ. Palatal stiffening after failed uvulopalatopharyngoplasty with the Pillar Implant System. Laryngoscope. 2006;116:1956-61.

174. Walker RP, Levine HL, Hopp ML, Greene D, Pang K. Palatal implants: a new approach for the treatment of obstructive sleep apnea. Otolaryngol Head Neck Surg. 2006;135:549-54.

175. Gillespie MB, Wylie PE, Lee-Chiong T, Rapoport DM. Effect of palatal implants on continuous positive airway pressure and compliance. Otolaryngol Head Neck Surg. 2011;144:230-6.

176. Li KK, Powell NB, Riley RW, Guilleminault C. Temperaturecontrolled radiofrequency tongue base reduction for sleepdisordered breathing: Long-term outcomes. Otolaryngol Head Neck Surg. 2002;127:230-4.

177. Riley RW, Powell NB, Guilleminault C. Inferior sagittal osteotomy of the mandible with hyoid myotomy-suspension: a new procedure for obstructive sleep apnea. Otolaryngol Head Neck Surg. 1986;94:589-93.

178. den Herder C, van Tinteren H, de Vries N. Hyoidthyroidpexia: a surgical treatment for sleep apnea syndrome. Laryngoscope. 2005;115:740-5.
179. Riley RW, Powell NB, Guilleminault C. Obstructive sleep apnea and the hyoid: a revised surgical procedure. Otolaryngol Head Neck Surg. 1994;111:717-21.

180. Stuck BA, Neff W, Hormann K, Verse T, Bran G, Baisch A, Duber C, Maurer JT. Anatomic changes after hyoid suspension for obstructive sleep apnea: an MRI study. Otolaryngol Head Neck Surg. 2005;133:397-402.

181. 2Prinsell JR. Maxillomandibular advancement surgery in a sitespecific treatment approach for obstructive sleep apnea in 50 consecutive patients. Chest. 1999;116:1519-29.

182. Riley RW, Powell NB, Guilleminault C. Maxillofacial surgery and obstructive sleep apnea: a review of 80 patients. Otolaryngol Head Neck Surg. 1989;101:353-61.

183. Hochban W, Brandenburg U, Peter JH. Surgical treatment of obstructive sleep apnea by maxillomandibular advancement. Sleep. 1994;17:624-9.

184. Riley RW, Powell NB, Guilleminault C. Obstructive sleep apnea syndrome: a review of 306 consecutively treated surgical patients. Otolaryngol Head Neck Surg. 1993;108:117-25.

185. Fujita S, Conway WA, Zorick FJ, Sicklesteel JM, Roehrs TA, Wittig RM, Roth T. Evaluation of the effectiveness of uvulopalatopharyngoplasty. Laryngoscope. 1985;95:70-4.

186. Chen SC, Shi S, Zheng HL, Chen DH, Zhu MH, Liu F, Tang HH, Wang K. Combination of genioglossus advancement by nontrephine technic with uvulopalatopharyngoplasty for treatment of obstructive sleep apnea-hypopnea syndrome. Zhonghua Er Bi Yan Hou Tou Jing Wai Ke Za Zhi. 2009;44:815-8.

187. Hendler BH, Costello BJ, Silverstein K, Yen D, Goldberg A. A protocol for uvulopalatopharyngoplasty, mortised genioplasty, and maxillomandibular advancement in patients with obstructive sleep apnea: an analysis of 40 cases. J Oral Maxillofac Surg. 2001;59:892-7. discussion 898-899.

188. Sundaram S, Bridgman SA, Lim J, and Lasserson TJ. Surgery for obstructive sleep apnoea. Cochrane Database Syst Rev 2005; CD001004.

189. Paoli JR, Lauwers F, Lacassagne L, Tiberge M, Dodart L, Boutault F. Craniofacial differences according to the body mass index of patients with obstructive sleep apnoea syndrome: cephalometric study in 85 patients. Br J Oral Maxillofac Surg. 2001;39:40-5.

190. Kao YH, Shnayder Y, Lee KC. The efficacy of anatomically based multilevel surgery for obstructive sleep apnea. Otolaryngol Head Neck Surg. 2003;129:327-35.

191. Liu SA, Li HY, Tsai WC, Chang KM. Associated factors to predict outcomes of uvulopharyngopalatoplasty plus genioglossal advancement for obstructive sleep apnea. Laryngoscope. 2005; 115:2046-50. 